\title{
Diet and association of Pontonia pinnophylax occurring in Pinna nobilis: insights from stable isotope analysis
}

\author{
H. Kennedy* ${ }^{\ddagger}$, C.A. Richardson*, C.M. Duarte ${ }^{\dagger}$ and D.P. Kennedy* \\ *School of Ocean Sciences, University of Wales-Bangor, Menai Bridge, Ynys Mon, LL59 5EY. †nstituto Mediterráneo de Estudios \\ Avanzados, CSIC-Univ, Illes Balears, C/Miquel Marqués 21, 07190 Esporles, Islas Baleares, Spain. \\ ${ }^{\ddagger}$ Corresponding author, e-mail: h.a.kennedy@bangor.ac.uk
}

\begin{abstract}
Stable carbon isotope measurements $\left(\delta^{13} \mathrm{C}\right)$ were used to assess the sources of carbon assimilated by the fan mussel Pinna nobilis, in sea grass Posidonia oceanica meadows, and an associated shrimp Pontonia pinnophylax which occurs within this bivalve's mantle cavity. The primary carbon sources available to both animals displayed a wide range of $\delta^{13} \mathrm{C}$ values, from -12.3 to $-22.3 \%$. The $\delta^{13} \mathrm{C}$ and $\delta^{15} \mathrm{~N}$ of Pinna nobilis and Pontonia pinnophylax suggest that they assimilate carbon from similar sources, occupy comparable trophic levels and that their association is commensal.
\end{abstract}

Pinna nobilis (Linnaeus, 1758) is a large, rapidly growing suspension feeding bivalve indigenous to the Mediterranean and is usually found in sea grass meadows (Butler et al., 1993; Yonge, 1953). The shrimp, Pontonia pinnophylax (Otto, 1821), which is up to $45 \mathrm{~mm}$ long, inhabits the mantle cavity of the living Pinna nobilis (Richardson et al., 1997). Pontonia pinnophylax has been observed to feed on the mixture of mucus and food particles collected on the gill surfaces and on the mantle epithelium of Pinna nobilis and expelled as pseudofaeces (Yonge, 1953). The objectives of this study were to investigate the potential use of stable carbon isotope analysis for determining the source(s) of organic matter that constitutes the diet of these two consumers and to use nitrogen isotope analysis to study the relationship between the shrimp and its pinnid host.

Eleven P. nobilis were collected from Posidonia oceanica sea grass meadows on the south-east Spanish Mediterranean coast, about half the Pinna nobilis contained solitary or paired Pontonia pinnophylax (Richardson et al., 1997). Two complete P. pinnophylax and the excised muscle of three Pinna nobilis were selected for analysis. The main carbon sources available to $P$. nobilis and Pontonia pinnophylax were collected, including suspended particulate matter (SPM) separated by vacuum filtration onto precombusted GF/F filters; the youngest sea grass leaves with no apparent epiphyte cover; epiphytes removed from older leaves, macroalgae and sieved $(<63 \mu \mathrm{m})$ surface sediment samples. Two Pinna nobilis were maintained in a tank of seawater and pseudofaeces collected. Samples were transported to the laboratory frozen, dried and where appropriate, homogenized. For isotopic analysis of the organic matter $\left(\delta^{13} \mathrm{C}, \delta^{15} \mathrm{~N}\right)$, subsamples were loaded into precombusted silver boats $\left(500^{\circ} \mathrm{C}, 3 \mathrm{~h}\right)$, acidified, in situ, with $\mathrm{HCl}(10 \%)$ and combusted $\left(910^{\circ} \mathrm{C}, 3 \mathrm{~h}\right)$ under vacuum. The overall analytical precision, using a SIRA Series II mass spectrometer, for both $\delta^{13} \mathrm{C}$ and $\delta^{15} \mathrm{~N}$ was $0.1 \%$ based on analyses of an internal laboratory organic standard.

The carbon isotopic composition $\left(\delta^{13} \mathrm{C}\right)$ of the primary sources of organic matter are shown in Figure 1. Terrestrially derived SPM $\left(\delta^{13} \mathrm{C}_{\text {terrestrial }}\right.$ : $\left.-27.1 \%\right)$, collected from a river discharge, reflected the input of predominantly C3 plants. The average $\delta^{13} \mathrm{C}$ of SPM collected at six locations, both inside and above the sea grass canopy, was $\delta^{13} \mathrm{C}_{\mathrm{SPM}}$ : $-22.3 \%(1 \sigma=1.4$, $\mathrm{N}=12)$. The epiphytes $\delta^{13} \mathrm{C}_{\text {epiphytes }}$ : $-18.9 \%(1 \sigma=1.5, \mathrm{~N}=12)$ and macroalgae, $\delta^{13} \mathrm{C}_{\text {macroalgae }}$ : -17.4 and $-17.8 \%$ values were similar but more negative than the sea grass $\delta^{13} \mathrm{C}_{\text {sea grass }}$ : $-12.3 \%$ $(1 \sigma=0.6, \mathrm{~N}=11)$. The isotopic value for the fine fraction $(<63 \mu \mathrm{m})$ of the sediment, $\delta^{13} \mathrm{C}_{\text {sediment }}:-21.4 \%(1 \sigma=1.5, \mathrm{~N}=4)$ was similar to $\delta^{13} \mathrm{C}_{\mathrm{SPM}}$.

The isotopic composition of the pinnid $\left(\delta^{13} \mathrm{C}_{P . n o b i l i s}\right)$ was $-18.3 \%$, $(1 \sigma=0.6, \mathrm{~N}=3)$. Using the average values for $\delta^{13} \mathrm{C}_{\text {sea grass }}, \delta^{13} \mathrm{C}_{\text {epiphytes }}$ and $\delta^{13} \mathrm{C}_{\mathrm{SPM}}$ and assuming that these are the major carbon pools ingested, the possible ranges for their contribution to the pinnids diet can be estimated (Dauby, 1989). The range in proportion of three carbon sources are SPM from 0 to $60 \%$ (25-70\%), epiphytes 0 to $98 \%(0-75 \%)$ and sea grass 0 to $40 \%(0-30 \%)$, where the values in parentheses have been calculated assuming a $1 \%$ enrichment of $\delta^{13} \mathrm{C}_{P \text { nobilis }}$ relative to its diet. The average proportions are SPM:epiphytes:sea grass $3: 5: 2$ or $5: 4: 1$ when the $1 \%$ enrichment is included. The $\delta^{13} \mathrm{C}_{\text {pseudofaeces }}$ : -24.1 and $-22.0 \%$ from the pinnid was about $0-2 \%$ more negative than $\delta^{13} \mathrm{C}_{\mathrm{SPM}}$. The presence of mucus in the form of proteinpolysaccharide complexes, may contribute to the more negative values for the pseudofaeces (Macko et al., 1989). The $\delta^{13} \mathrm{C}_{P \text {. pinnophylax }}$ : -18.4 and $-19.0 \%$ means that it is unlikely that pseudofaeces is the sole component of the shrimp diet. If pseudofaeces is substituted for SPM, the average ratio of pseudofaeces:epiphytes:sea grass in the shrimp diet is $4: 5: 2 \quad(4: 7: 0)$ for $\delta^{13} \mathrm{C}_{\text {pseudofaeces }}$ : $-22.0 \%$ and 3:5:2 (4:4:2) for $\delta^{13} \mathrm{C}_{\text {pseudofaces }}$ : $-24.1 \%$ where the values in parentheses are those calculated assuming a $1 \%$ enrichment of $\delta^{13} \mathrm{C}_{P \text {. pinnophylax }}$ relative to its diet.

Whereas $\delta^{13} \mathrm{C}$ values are used to discern between important primary food sources, $\delta^{15} \mathrm{~N}$ values allow the determination of trophic levels, as $\delta^{15} \mathrm{~N}$ is typically enriched by $3-5 \%$ per trophic level position. Data $\left(\delta^{13} \mathrm{C}\right.$ and $\left.\delta^{15} \mathrm{~N}\right)$ analysed in this study and literature data on other Mediterranean sea grass ecosystems have been used to provide an indication of feeding strategy and presumed trophic position of the pinnid and shrimp (Figure 2). There is about $1 \%$ difference between $\delta^{15} \mathrm{~N}_{P \text { nobilis }}: 3.3 \%$ o $(1 \sigma=0.2$, $\mathrm{N}=3$ ) and $\delta^{15} \mathrm{~N}_{P \text {. pinnophylax }}: 4.6$ and $3.9 \%$, which indicates they are likely to occupy similar trophic levels. The $\delta^{15} \mathrm{~N}_{P \text {. nobilis }}$ and $\delta^{15} \mathrm{~N}_{\text {P. pinnophylax }}$ are $2-3 \%$ more positive than either the pseudofaeces or the SPM and this difference is close to the range of expected values for diet-tissue fractionation. To be consistent with the $\delta^{13} \mathrm{C}$ data used to calculate proportions of SPM : 


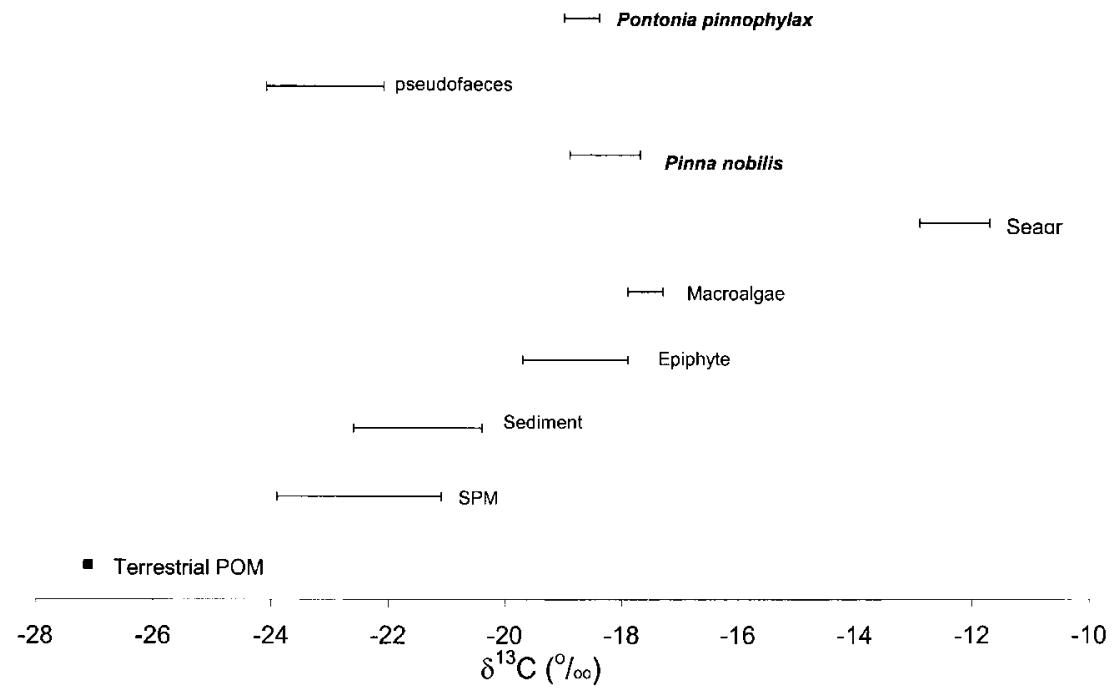

Figure 1. Range in stable carbon isotope composition $\left(\delta^{13} \mathrm{C}\right)$ of Pinna nobilis, Pontonia pinnophylax and of potential dietary carbon sources. Values are the mean $\pm 1 \sigma$.

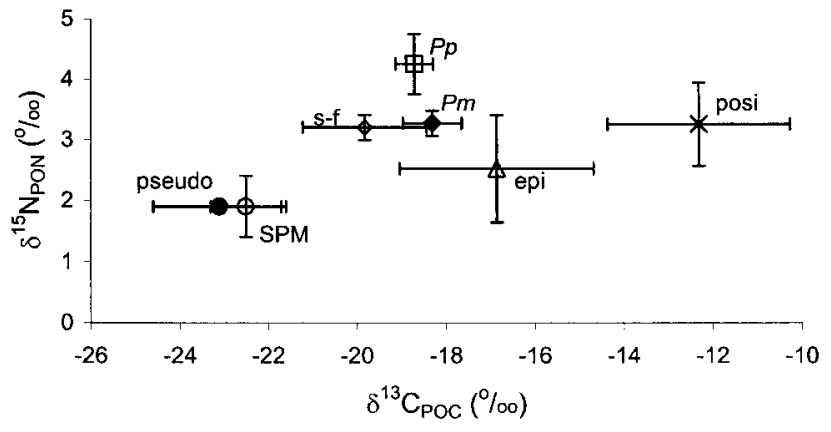

Figure 2. Mean values $( \pm \mathrm{SD})$ of $\delta^{13} \mathrm{C}$ and $\delta^{15} \mathrm{~N}$ of Pinna nobilis, $(P n, \bullet)$ its pseudofaeces (pseudo, $\bullet$ ) and Pontonia pinnophylax $(P p, \square)$ measured during this study and additional SPM $(0)$, suspension feeders (s-f, $\diamond)$, epiphytes (epi, $\Delta$ ) and sea grasses (posi, $\times$ ). Data taken from Dauby, 1989; Havelange et al., 1997; Jennings et al., 1997; Lepoint et al., 2000.

epiphytes:sea grass in the animal's diet, $\delta^{15} \mathrm{~N}_{\text {epiphytes }}$ would have to be similar to $\delta^{15} \mathrm{~N}_{\mathrm{SPM}}$. The available data (Jennings et al., 1997; Lepoint et al., 2000) does not appear to support these conclusions (Figure 2). However, the sea grass epiphyte community consists of both sessile plants and animals, therefore $\delta^{15} \mathrm{~N}_{\text {epiphytes }}$ can vary by $\sim 3 \%$ depending on the proportion of plants and animals in the community. Thus the premise that epiphytes contribute a significant component of the pinnid and shrimp diet would not be inconsistent if the epiphyte community had a high proportion of plants at our study site.

The stable isotopic data reported here demonstrate Pinna nobilis and Pontonia pinnophylax assimilate similar food sources, with the shrimp occupying a similar trophic level to its host. Hence the association between P. pinnophylax and Pinna nobilis appears to be commensal or symbiotic, using the host for protection and possibly food entrapment.

We would like to thank L. Hooper and Dr S. Wood for their help during the fieldwork and the authorities of the Parque Natural del Cabo de Gata-Nijar for permission to work in the
Park's waters. Support was provided by the joint British CouncilSpanish Ministry of Education Programme Acciones Integradas (Ref 50B), project CL 195 - 1805 of CICYTand the Ministerio de Educatión y Gulture, Spain.

\section{REFERENCES}

Butler, A., Vincente, N. \& Gaulejac, B. de, 1993. Ecology of the pterioid bivalves Pinna bicolor Gmelin and Pinna nobilis L. Marine Life, 3, 37-45.

Dauby, P., 1989. The stable carbon isotope ratios in benthic food webs of the Gulf of Calvi, Corsica. Continental Shelf Research, 9, 181-195.

Havelange, S., Lepoint, G., Dauby, P. \& Bouquegneau, J.-M., 1997. Feeding of the sparid fish Sarpa salpa in a sea grass ecosystem: diet and carbon flux. Marine Ecology. Pubblicazione della Stazione Zoologica di Napoli I, 18, 289-297.

Jennings, S., Renones, O., Morales-Nin, B., Polunin, N.V.C., Moranta, J. \& Coll, J., 1997. Spatial variation in the ${ }^{15} \mathrm{~N}$ and ${ }^{13} \mathrm{C}$ stable isotope composition of plants, invertebrates and fishes on Mediterranean reefs: implications for the study of trophic pathways. Marine Ecology Progress Series, 146, 109-116.

Lepoint, G., Nyssen, F., Gobert, S., Dauby, P. \& Bouquegneau, J.-M., 2000. Relative impact of a sea grass bed and its adjacent epilithic algal community in consumer diets. Marine Biology, 136, 513-518.

Macko, S.A., Helleur, R., Hartley, G. \& Jackman, P., 1989. Diagensis of organic matter - a study using stable isotopes of individual carbohydrates. Advances in Organic Geochemistry, 16, 1129-1137.

Richardson, C.A., Kennedy, H., Duarte, G.M. \& Proud, S.V., 1997. The occurrence of Pontonia pinnophylax (Decapoda: Natantia: Pontoniinae) in Pinna nobilis (Mollusca: Bivalvia: Pinnidae) from the Mediterranean. Fournal of the Marine Biological Association of the United Kingdom, 77, 1227-1230.

Yonge, C.M., 1953. Form and habit in Pinna carnea Gmelin. Philosophical Transactions of the Royal Society B, 237, 335-374.

Submitted 14 September 2000. Accepted 17 November 2000. 